\title{
Has Ever Brahmaea Ledereri Rogenhofer, 1873 Inhabited the Colchis Refugium
}

\author{
Arnold Gegechkori ${ }^{1}$, Eter Didmanidze ${ }^{2}$ \\ ${ }^{1}$ Department of Biodiversity, Faculty of Exact and Natural Sciences, Iv.Javakhishvili Tbilisi State University, Tbilisi, Georgia \\ ${ }^{2}$ Georgian National Museum, Tbilisi, Georgia
}

Email address:

arngegechkori@yahoo.com (A. Gegechkori), lepidopterology@mail.ru (E. Didmanidze)

\section{To cite this article:}

Arnold Gegechkori, Eter Didmanidze. Has Ever Brahmaea Ledereri Rogenhofer, 1873 Inhabited the Colchis Refugium. American Journal of Environmental Protection. Special Issue: Applied Ecology: Problems, Innovations.Vol. 4, No. 3-1, 2015, pp. 82-92.

doi: 10.11648/j.ajep.s.2015040301.24

\begin{abstract}
The biogeographical background. There are two refugial centers in Transcaucasia: Colchis (along the Black Sea coast) and Hyrcan (Hyrcania) (along the Caspian Sea shore). Elements from Europe and Asia and their biogeographical subdivisions compose flora and fauna, which combined with the diverse geomorphology (Laurasian, Gondvanian), the presence of the impressive mountain ridge of the Great Caucasus, its insularity during 100 million years (from Cretaceous time), have resulted in a high taxonomic (species, genera) richness and endemism. The both refugiais characterized by a rather uniform thermical indexes, considerably the former one. The both shelters consist of an extraordinary abundance and diversity of thermophilic woody flora (trees, shrubs and vines) belonging to Arcto-Tertiary Geoflora. Except species typical for nemoral biota, there are extremely rare species of tropical-subtropical origin, which became extinct in South Caucasus during the Tertiary (at the close of the Pliocene) climate deterioration. In response to cooling climate and physiographic changes, some rare genera became restricted to both refugia of Transcaucasia. Most of them are now confined chiefly within the Hyrcanianrefugium (species of Albizia, Gleditsia, Panthera, Hystrix). Among the invertebrate fauna of Tertiary origin should be considerably mentioned species of remarkable nocturnal Brahmin moth - Brahmaea Walker. The interdisciplinary study of the orthodox view regarding the vicariant event between two species of moths as thoughthey are indigenous of Colchis $(B$. ledereri) and Talysh $(B$. christophi) does not actually exist. The reason circumstances to express such opinion remain important due for a variety of reasons which are given below.
\end{abstract}

Keywords: Colchis, Hyrcan, Refugia, Biogeography, Brahmaea ledereri

\section{Introduction}

In the moderate climate belt of the North Hemisphere is represented broad-leaved deciduous, summer-green forest zone (biome). In biogeographical literature, it is determined as a Temperate Broad-Leaved Deciduous Forests (TBDF) [1, 2]. By geobotanists this thermophilic dendroflora are proposed as the Arcto-Tertiary Geoflora [1,2]. Sometimes TBDF complex mentioned as a Nemoral Flora [3] within these communities participate some warm climate loving summer-green arboreal plants (sweet chestnut, beeches, oaks, zelkova, etc.), conifers (yew tree, tsuga, sequoia, etc.) [4]. After the Pliocene climate deterioration, representatives of the TBDF grow preserving in local places, restricted in refugial areas [5]. Two the largest and richest with the Arcto-Tertiarry relicts' regions in the western Eurasia are situated in the south Caucasus and adjacent some countries [6, 8]. One of it, Hyrcanian province (subprovince) includes the Caspian Sea coast area and northern slopes of the Alborz mountains range in North Iran. Its smaller northwestern site, Talysh, represented in the southeast Transcaucasia (Republic of Azerbaijan) [7]. The second large harbor is Colchis. This region, the main part of anEuxinian province (subprovince) covers eastern and southeastern part of the Black Sea (coast area and adjacent slopes of the Greater and the Lesser Caucasus). It includes main part of West Georgia, Krasnodar district of Russia and north-eastern Turkey [6]. All of these regions and districts are present the Caucasus Ecoregion (480.000 sq.km.) [6].

Physical-geographically, the two regions extend from $35^{\circ}$ to $45^{0}$ latitude [6]. 
Among the Caucasus biomes, the floristic and faunistic diversity and infrequency (relict and endemic plant and animal species) of forests of mentioned two refugia are one of the most striking feature of the Ecoregion $[8,9]$. The central place of the most humid area is occupied by south Colchis with West Georgia's province, Adjara $\left(41^{0} 21\right.$ 'and $\left.41^{\circ} 53^{\prime} \mathrm{N}\right)$, refugium in refugium, with considerably humid and warm temperate (oceanic) climate. January mean temperatures are above $0^{0} \mathrm{C}$, and maximum precipitation is known from the Mt Mtirala ('Crying Mountain' - from Georgian), namely $4520 \mathrm{~mm}$, which is record data for the Caucasus Isthmus [9], and the Former Soviet Union (FSU).

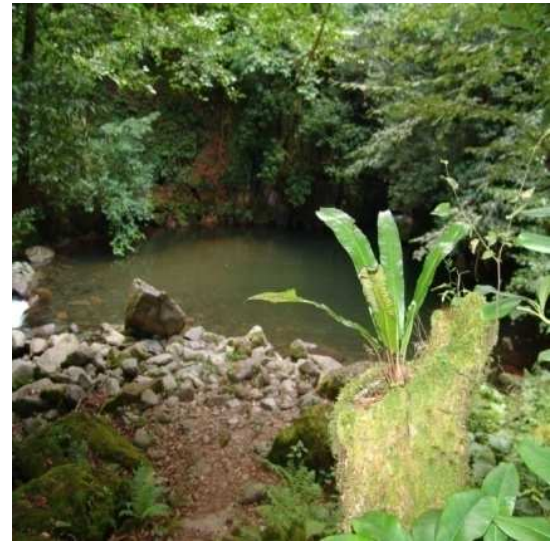

Figure 1. The typical site of the Mtirala gorge (Adjara).(All photos belong to A. Gegechkori).

Except the narrow sea coastal area, it is typical mountainous district of Georgia, which occupied Adjaro-Imeretian (Meskheti Range) mountain system of the Lesser Caucasus [6]. Adjara with adjacent another province of West Georgia Guria and neighboring to the northwestern part of Turkey is richest in endemic and relict species. Orographically it is represented as part of Western Lesser Caucasus (WLC), which is largely known as a Major Forest Refugium. WLC belongs to the Eastern Euxinian or Colchianphytogeographic province [10].

If phytocenoses of Talysh is favorable with its archaic representatives in the canopy (species of Parrotia, Quercus, Acer) [7-8], the Colchis shelter is impressive with its understory (especially species of Rhododendron) [5].

Derivative forms of relict fauna are an inseparable component of Arcto-Tertiary woody communities of both refugia, especially to Talysh. Mentioned should be species of following genera: Brahmaea Walker, Isophya Wattenwyl, Parandra Latreille, etc. [11].

\section{Results and Discussion}

Endemic and relict species of any refugia are of exceptional biological and biogeographical interests. Refugial centers sheltering such species are frequently referred to as a biodiversity hotspot. They have a prominent role in conservation biology [12].

The most vivid example of relict and at the same time endemic species are manifested by genus Brahmaea (Brahma - the creator, major god of Indian religion) $[11,28]$. Brahmin moths, family Brahmaeidae, of 28 species are found in the tropical latitudes of Ethiopian and Oriental zoogeographical Regions, and extending north into the warmer area of temperate localities of Palearctic.

The family takes its taxonomic place in superfamily Bombycoidea and consists itself by two subfamilies: Dactyloceratinae and Brahmaeinae [13]. Adults of Brahmin moth species are large: wingspan varies from 50 to $180 \mathrm{~mm}$. Species occur in tropical-subtropical biomes have circular 'eye' markings on their wings ('Owl Moths'). This complex of moths regarding to independent genus Brahmophthalma Mell by some entomologists $[14,15]$. The other ones are from temperate climate biomes, without these markings - to Brahmaea (sensustricto) [16]. The Brahmid moths have most complicated wing patterns of any Lepidoptera [16]. Leaf feeders, larvae are recorded in Asclepiadaceae and Oleaceae $[17,18,19]$.

Brahmaidae at present include four recognized genera: Brahmaea Walker (type genus of the family), genus represented in Oriental and Palearctic Regions (8 species); AcanthobrahmaeaSauter, a monotypic European genus; Calliprogonos Mell, a monotypic Chinese genus; Dactylocerus Mell, an Afrotropical genus of about eight species; by some authors within mentioned family is considered also Lemonia Hübner in Palearctic with about twenty species [20,21,22]. The range of Brahmaea spp. in the temperate climate area is complex, involving several refugia. Present-day as a minimum 5-6 species of this genus have become an endemics of local regions of the Palearctic: $B$. tancrei Austaut (Russian Far East, Korea), B. certhia Fabricius (Sino-Korean, but from southern China most likely more), B. litserra Hao, Zhang \& Yang(northern China), B. japonica (Butler) (from Japan), B. (Acanthobrahmaea) europaea Hartig (from Italy), B. ledereri Rogenhofer (Turkey and adjacent small area of Syria). Hyrcanian B. christophi Staudinger by some authors treated as a subspecies of $B$. ledereri $[23,24]$, subspecies - B. ledereri zabade Freina occurs in extreme easternward of Anatolia (Turkish Kurdistan region). It shows intermediate features between latter two species [25].

Despite mentioned data, the Brahmaeidae seem to have been little studied and literature sources are very scanty [16]. There are apparently 15 species and 4 genera in China alone [16]. Sometimes information about Brahmid moths similar to genera including in Brahmaeidae, are quite controversial. For example, B. ledereri and B. christophi are mentioned in Chinese complex of these moths[14]; then, according to another source, $B$. ledereri in Chinaamong the other species of this genus feeds on Ligustrumsinense [26].

Therefore, "Eurasiatic species of Brahmaeidae present polymorphic populations with an uneven geographic distribution. The disputed taxonomy of this group is also due to the occurrence of populations that show morphological characteristics intermediate between related species" [20].

Among relict and endemic species of South Caucasus 
refugia species of genus Brahmaea have emerged as of great interest to biogeographers due disjunct distribution area [7,11] but are there within two refugia - Colchis and Hyrcanvicariant event of Brahmid moths?

It should be stressed that among the relict fauna of Colchis, stenopaleoendemic $B$. ledereriis very problematic species for this region till today. A controversial information of its occurrence in perhumidhabitats of Colchis lowland and foothills arises chiefly from very old, questionable and with a large probability incorrect records. It seems to be doubtful the presence of this species along the eastern and southern Black Sea coast supposedly as a result of wrongly given locality in scientific literature [27]. Lepidopterologist Dr. E. Didmanidze in her's monograph 'The butterflies of Georgia' [28] wrote: 'In collections of the museum (Georgian National Museum A.G.) only one specimen of $B$. ledereri is preserved, label of which is ' 1875 ' (Romanoff's collection)'. In another unpublished paper Didmanidze and Goginashvili [30] underline: 'The first summarized information on Brahmin moths of South Caucasus is summarized by N. Romanoff (1885) [65] in which is indicated Brahmaealedereri from "Batumi province".

The next important information includes the catalogue by Staudinger and Rebel (1901) [29]. In this work as a first site ofBrahmin ledereri's moth finding, followed to Rogenhofer, who described $B$. ledereri, is named 'Taur.os' (with following sites in German language: 'Gebirgsgebeitvom Bulghar-daghbis Gjaur-daghmit den OrtenHadjin, Zeitun, Marasch and Akbes (Eibes)' [30].

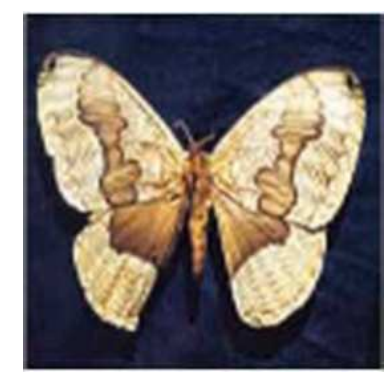

Figure 2. Brahmaealedereri from collections of the Georgian National Museum.

Latter existence of a Brahmin moth in Adjara (Batumi) is indicated by famous Russian lepidopterologists Ryabov [31] in his valuable 'Butterflies of the Caucasus'. This view seems to be 'turning point', i.e. a series of articles based on misunderstandings, as though the presence of 'relict moth' in Western Lesser Caucasus (Adjara). This viewpoint was largely motivated to the former Soviet Union's entomologists have been manifested 'everybody and together': tropical-subtropical fauna including $B$. ledereri of West Georgia as 'Colchis' ones. In this context, to show typical erroneous scholarly sources, should be quote Didmanidze [28]: 'It is very rare species of Tertiary Period and endemic of Colchic (mixed broad-leaved forests -A. G. ), included in the 'Red Book of the USSR'; or 'on the territory of the Caucasusoccur only two species of this scanty tropical genus, B. christophiis one of them'; then 'on the territory of Georgia lived Colchicbrahmaea $-B$. ledereri Rogenhofer 1873, but after the beginning of XX century, in spite of regular inspection of typical area, this species was not found anymore'. This point of view that this moth could be considered extinct, i.e. Regionally Extinct (RE) in West Georgia is shared by almost all the entomologists of the Caucasus and the former USSR [31,38-44].

Despite of mentioned viewpoint, Lederer's moth as a live species of Colchis biota is still indicated by some authors [7,11,28,32-37,64].

A complex of reasons has led co-author of the present article [27] to look carefully into the relict distribution of this archaic species upon in humid ecosystems of the Black Sea coastal area.

Colchis as a region is situated in the temperate climate zone supporting temperate and humid biome with broadleaf and mixed forests. It has an extremely impoverishment species of humid-tolerant tropical-subtropical and Mediterranean, sub-arid type of subtropical flora and fauna within this (Colchis) marginal parts of their range (f. e. species of Hymenophyllum, Arbutus, Erica, etc.) [41-44]. However, viewed over the entire Quaternary, if any taxa survived glacial-interglacial cycles in Transcaucasia, with a great probability it should be found in a contemporary refugial locations. One of such stable shelter is Colchis forests composed of thermophilic broad-leaf deciduous and coniferous dendroflora. The latter was not endangered through changes in timber composition [5, 9, 10,45, 46].

It is doubtful whether species like $B$. ledereri has become extinct across all Colchis, still less in southern Colchis, i.e. outpost region for many relictual plant and animal species. For example, relict moth Phassusschamyl, the salamander of Miocene time Mertensiellacaucasica, another 'dying relict' (plant) Epigaeagaultheroides, and others [28,45-47].

B. ledereri unlikely to be extincted because of in South Colchis still exists required to this moth large areas of hygro-thermophilous, close to primeval broadleaf forests with complex habitats.

This is especially true for some gorges of Adjara district, which are really impressive with lush flora, sheltering a number of outstanding ancient living organisms [44-46, 48]. Some of most important from this viewpoint sites are represented as a Natural Parks (Kolkheti National Park, Mtirala National Park) or reserves (Kintrishi State Nature Reserve, Kobuleti State Reserve). Some reserves in Adjara were founded in the 1950 s and 1960 s, i.e. after 50-60 years later of as though extincted data of $B$. ledereri.

It should be stressed that Mtirala NP (and neighboring other sites) with its Arcto-Tertiary deciduous forests develops as in the extremely moist gorges is more 'tropical site' than those of Talysh (Azerbaijan), which shelter another relict species - $B$. christophi $[8,11,41]$.

The same requiring habitats of Brahmid moths are largely represented along the neighbouring Turkish Caucasus (part of WLC), in the Pontic Mountains (Pontids) and Lazistan, which runs as a narrow stripe along the same southern coast of the Black Sea. It should be stated that Lederer's moth is not 
recorded in Lazistan till today $[49,50]$.

Despite Brahmin moth's official conservation status as Regionally Extinct (RE), sightings are still continuous, though none has been conclusively proven. It should be mentioned two recent attempts of positively decision of this problem. For example, a joint expedition carried out by Zaguliaev (St.-Petersburg), Didmanidze (Tbilisi), Jobaba (Kobuleti, i.e. Adjara). During 3 years (1983-1985) was collected a rich fauna of butterflies including nocturnal moth species [30]. At the same time pictures (photos) of the moth were allotting to residents of different gorges of Adjara to recognize the imago, thus being identities unmistakably to this species of Brahmid moth; Jobava himself was ready to take pictures of life-cycle stages of $B$. ledereri.

Another attempt to collect this species of moth was put into practice in 2010-2011 (in Adjara) and 2012 (in adjacent to Adjara Turkish part of Colchis refugium, Goruh River Valley). One of the main goals of expeditions was to collect caterpillars of moth on, as though food plant, Osmanthus decorus in both states. The material was collecting by light trapping (PRK-2 lamps) at night, netting by day, and looking for caterpillars in daytime. In four different elevations of the Kintrishi River Gorge outstanding by its relict species of vegetation light traps were used including constantly operative Sakharov's insectrapping. The last trip was granted by the Rustaveli National Science Foundation. All these attempts to collect $B$. ledereri had no results [30].

It is difficult to judge whatever during last century microorganism diseases (fungal and others) through epidemiology can cause severe, demonstrable impact against vulnerable relict invertebrate animal species of Colchis, including Lederer's moth.

As regards to predators, species of genus Brahmaea, similar to most tropical butterflies, to escape predation, adult insects will hide through mimicry (cryptic coloration: on the example of $B$. Ledereri the ground color is dark-brown, ornamented with many parallels, finally wary-curly lines of white-rose color). Important cryptic selective advantage provides theirs slow flying (during daytime adults reston tree trunks). Cryptic anatomy and coloration is exemplified by large caterpillars as well [28].

This fact that ecological parameter of some temperate deciduous forests is attractive for exotic insects is confirmed by colonizing of Colchic 'rainforest' with saturnid moth. During $20^{\text {th }}$ century western Georgia was enriched with tropical-subtropical Ailanthus silkmoth (Samiacynthia). It was introduced in Georgia for sericulture development. The moth did not domesticate as the silkworm unlike $S$. cynthiariciniin India (it is the only completely domesticated silkworm other than Bombyxmori). Indigenous populations of S. cynthiaoccur in China and Korea. In some countries of all continents, like Caucasus, it escaped from cultivation and naturalized [28]. It 'adapted to the natural conditions, has become a part of the Caucasian peacockbutterflies fauna and today is distributed in the total subtropical belt of the Georgian Black Sea coastal line' [28].

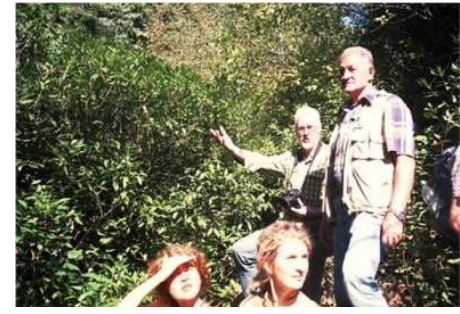

Figure 3. The stand of the Osmanthusdecorus in Adjaristskali valley (Adjara).

According to Ryabov [31], Borodin et al. (Eds.) [33] and Didmanidze [28], Didmanidze and Petrov [40], the caterpillars of $B$. ledererifeed on Osmanthus (Phillyrea) decorus and as it seems on other arboreal plants of Oleaceae, within the community usually found Castanea sativa in over forest and Alnusbarbataand Corylussp. in second stratum of forests. The stand of $O$. decorus usually occurs in subcanopy in Adjara and Guriadistricts (Georgia) and in the adjacent Turkish Caucasus [48].

This record requires confirmation because of, as it was mentioned, there are no professional entomologists and naturalists who recorded feeding larva, i.e. insect (moth) host plant (O. decorus) associations in West Georgia and Lazitan.

According to Mandjavidze [48], O. (Phillyrea) decorus, is evergreen shrub or small tree. It is one of the most moist-tolerant species of its genus. $O$. decorusis restricted in Adjara to foothills and low mountain's slopes. Species typical within the group of noble hardwood include Oriental beech, sweet chestnut, European hornbeam, Oriental spruce, common ash tree (Fraxinus excelsior), Caucasian persimmon; understory is represented by Laurocerasus officinalis, Rhododendron ponticum, Staphyllea pinnata, S. colchica, Ilex colchica, Vaccinium arctostaphylos, etc. In marginal parts of forests it forms stands with Colchic boxwood. Therefore, in this community of deciduous forest there are some species of fam. Oleaceae (Fraxinus, Osmanthus), i.e. host plants of the moth.

If we take into consideration this fact that in typical Colchic woody community were organized numerous field excursions from Georgian National Museum and Zoological Institute RAS (St.-Petersburg) supplied by night moth trapping equipment, unlike to Hyrcanian forests, caterpillar-plant interactions research, as it was underlined, gave no positive results.

Finally, an additional confusion regarding the presence ofLederer's Brahmin in West Georgia should be originated from recent historical toponyms of the Colchis (Kolkheti) region. For example, 'Pontus' being an ancient name for the region around the Black Sea, and by extension, for the sea itself (en.wikipedia.org./wiki/Toponimy). Probably, these circumstances motivated entomologists of early $20^{\text {th }}$ to incorrect determine the toponime of $B$. ledereri finding site of the moth if it exists indeed. The same situation occurs regarding to principality of Kutaisi. In this principality during the Tsarist Russian Empire $\left(19^{\text {th }}\right)$ besides Imereti district of West Georgia was included Guria adjacent to Adjara. Hence, 
when in the past time for Osmanthusdecoruswas mentioned that this shrub grows in principality of Kutaisi it should be understood not Imereti region (Kutaisi is capital of this district) but Guria just from latter region was described Phillyreamedwedewi(i.e. Osmanthusdecorus) by Sredinski [48]. The same view seems to be based on misunderstanding for lepidopterologists. For example, they are emphasized as first collecting sites of discussed moth Batumi city (capital of Adjara - A.G.) vicinity [30,40], or moth's distribution in 'Adjara and Lazistan' [40], and believe that 'species is distributed in western Georgia, Colchis lowland. It is described from the Black Sea coast area (Lazistan) and inhabits in the same habitats, Colchic forests' [31], it is 'endemic and relict species of Pontic Province' [40], 'endemic of Colchis' [32, 33], 'endemic of Colchis and adjacent territory of the Black Sea coast of Turkey' [34], 'Colchis $B$. ledereriand TalyshianB. christophi' [35], 'AdjarianB. ledereri' [37, 64], etc.

Based on entomologists' data, now Lederer's moth is included in all regional (Caucasus, former USSR) and international (IUCN) Red Data Books and Red Lists [30, 42].

Today, B. ledereri is included in all 'Environmental Impact Assessment' types of issues dedicated to Colchis region of Georgia entitled 'Animals, included in the Red Data List of Georgia (2006), which can be found within the work area' (f.e., National Report on the State of the Environment of Georgia (2007-2009), 'Follow-up of Recommendation \#120 (2006) on a European strategy for the Conservation of Invertebrates. Report by the Goverments. Strasbourg, 3 November 2011).

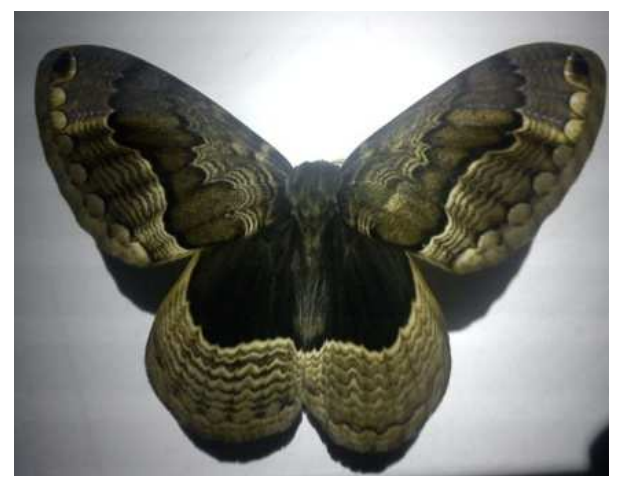

Figure 4. Brahmaeachristophi-new emerged from pupa imago (photo by $M$. Soufi, 2013).

The most vivid example of relict and at the same time endemic species are manifested by Brahmaeachristophi, one of the most beautiful moths in the invertebrate fauna of the extreme south-east Caucasus and Northern Iran [27-28, 30-44, 51-55].

$B$. christophi much resemblesTurkish vicarious species $-B$. ledereri, but is slightly larger (the wing-span reaches 110-130 mm (maximum - 160mm) vs $B$. christophi (95-107 mm) [28]. The latter species cover the whole Hyrcanian area, including Iranian part of the southern Caspian basin (Gilian, Mazandaran, Gorgan). The co-author of present work collected some specimens of this species with lepideptorologists R. Effendi and E. Didmanidze during several excursions in 1970s. At present four specimens of the moth are deposited in the collections of Georgian National Museum (Azerbaijan, Astara: 1910; Talysh, Hyrcanian relict forest, 14.04. 1974 (leg. Gegechkori), 17.04.1974 (leg. Didmanidze) [30].

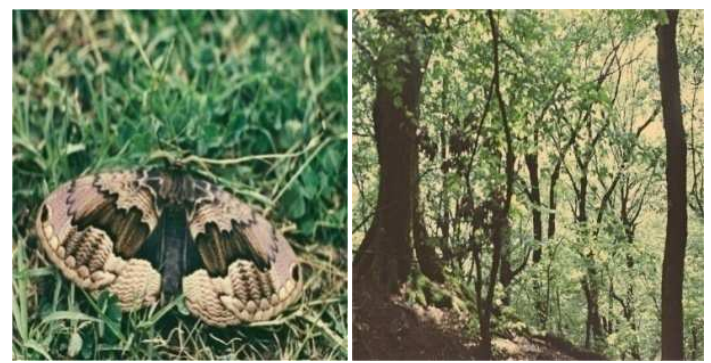

Figures 5-6. The forest composed by Parrotiapersica in overstory; Brahmaeachristophi caught in 1974 (Talysh).

The insect prefers the most damp and shady forests of gorges at the Talysh mountain from lowland up to $1,000 \mathrm{~m}$ a.s.1, i.e. the environment of its inhabitationwillmore or less resemble that of the subtropical-warm and humid climate of ancient geological epochs, when the waters of the Sarmatian Sea washed the coastal zone of the Caucasus Peninsula. The single glance at the genus Brahmaea is enough to became sure of how rich and lush thermophilous woody communities covered the Caucasus at the boundary of the Paleogene and Neogene Periods. Similar to Iran, Christoph's moth caterpillars feed on the leaves of native ash-tree (Fraxinus excelsior coriariifolia) [35]. Belonging to the relicts of immemorial time (about 30 mya), B. christophi close to extinction (Critically Endangered, CE) [37, 53].

A few publications refer to studies of the peacockbutterflies and considerably family Brahmaeidae of Northern Iran [54-56]. As a relict species of Miocene time B. christophiis now present in only a few populations in the Hyrcanian region (mentioned sources and pers. Observ. - A.G.). Present information was collected from local naturalists, from collections of museums of local National Parks during excursion of Gegechkori in Caspian forests (2012, X).

In Northern Iran this species occurs both in mesophilous Hyrcanian forests and more xeric variant of the same forests nearby to open woodlands and scrubs in Golestan Province northern of Golestan National Park (GNP).

One of the most xeric location of distribution B. christophi occurs near Totli Tamak village. This village and its surroundings are located northwestern part of GNP $(300 \mathrm{~m}$ away of NP border, northwestern Iran (620m a.s.1.) (Soufi, pers. comm.), annual precipitation ranging from 220 to 280 $\mathrm{mm}$ (Khorozyan, pers. comm.). Precipitation increases to $400 \mathrm{~mm}$ at the slopes of the Bylikooh Mountain area, which is adjacents to mentioned village (Soufi, pers. observ.).

The local semi-lush forest, where the new emerging Christof's moth was recorded $(900 \mathrm{~m}$ a.s.l., mentioned mountain area), consists of leading species of noble hardwood of Hyrcanian region. Major forest-building species include: Quercu scastaneifolia, Parro tiapersica, Carpinus betulus, Fraxinus excelsior ssp. coriariifolia; Diospiros lotus, Ficus 
hyrcana are represented as subcanopy trees; Populus caspica, Alnus glutinosa, Salix spp. are confined in riverine; Crataegu spentagina, C. monogyna, Mespilus germanica, Prunus divaricata, Danae racemosa frequently occur as understory in these communities. The ground vegetation is manifested by the presence of Primula heterochroma, Viola alba (Soufi, pers. comm., pers. observ.).

In adjacent semi-dry habitat mentioned communities are largely outcompeted by more xerophillous communities of Zelkova carpinifolia and Pyrus boissieriana. In the more xeric variants of the site is phytocenoses, where the leading species are shrubs like Paliurus spina-christi and Rhamnus pallasii (pers. observ.).

The flight of the moth is observed in April, at night. In daytime adults (the imago) were observed resting with wings spread out on a tree trunk of the dominant forest tree, chestnutleaf oak.

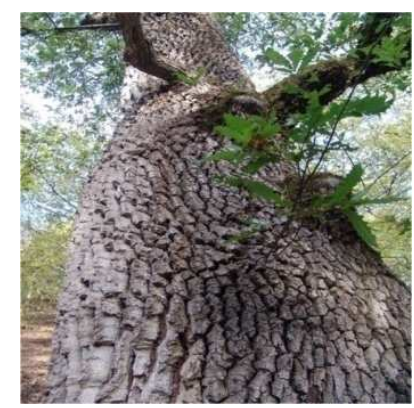

Figure 7. The trunk of the magic oak (Quercuscastaneifolia) near TotliTamak village (about $900 \mathrm{~m}$ a.s.l.).

Adult of $B$. christophiwas observed after emerging from the pupa in the spring, which already indicate the species can permanently bread in not far of rural landscapes situated in the borderland near GNP. This site has now been rather intensively utilized for agriculture and logging. Thus, at present it occurs regularly in this locality.

The species is endangered by changes in forestry management in non-preserved sites of the moth's range (Soufi, pers. comm.).

In collections of the museum of GNP is exhibited one specimen of $B$. christophi. It was taken in 1980 by ranger also from transition zone of NP. TangeGol similar to TotliTamak village, it is characterized by mosaic semi-lush and semi-dried landscapes.

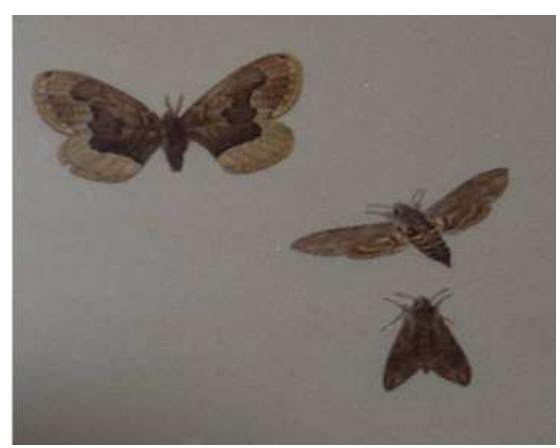

Figure 8. Brahmaeachristophi (upper specimen) in collection of the Museum of Golestan National Park.
German and Austrian scientists (Gutleb and Wieser) have discovered Cristoph's moth in TangeGol (2001) as well (Soufi, pers. comm.).

From mentioned peculiarities can be concluded:

1. Unlike all other species of the genus Brahmaea, B. christophi in the Iranian part of the Hyrcanian subprovince is ecologically most plastic species. It inhabits both Gilan-Mazandaran humid 'rainforest' and semi-dry, northeastern part of Iran (northern of GNP); it occurs on the one hand in undisturbed non-urban sites of GNP and some other reserves, and on the other hand in area represented in surrounded by modern homogenous rural land; GNP provide a meeting area for the Caspian Sea coastal and foothills taxa with semi-arid mountain taxa of living organisms, e.g. in the case of the transition zone between the Euro-Siberian (with Euxino-Hyrcanian province) and Irano-Turanian taxa.

2. Outside conservation area, occupying sub-xerothermic sites on the border of National Park and severely reduced numbers in typical habitats population of Christoph's moth are highly endangered.

Currently, as it was already mentioned, Talysh (Azerbaijan) and adjacent Caspian Sea coastal area of Iran represent relict ecosystems of summer-green warm temperate forests i.e. Major Forests Refugium, sheltering many rare and endangered species including stenopaleo endemics of plants and animals. As unique biome including unique forest composition and floristic and faunistic richness worldwide, it is urgent goal of environmentalists to synergize all activities in order to conserve native biodiversity like, for example, Hyrcan and Golestan National Parks. Therefore recognizing of having great value to strict conservation and management policies, it is urgent need to establish Iran-Azerbaijan crossand transboundary cooperation for Hyrcan highly complex biodiversity conservation [57].

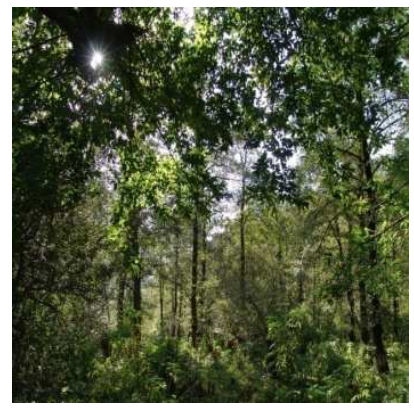

Figure 9. The pristine forest of Hyrcanianrefugium, Mazandaran province.

On the other hand, review of literature sources and private findings of Freina [23,25] in southwestern, eastern and southeastern Turkey have make the further light on distribution pattern of $B$. ledereri. His research on taxonomy [23], chorology and biology [25] of the moth showed following: firstly, the range of moth includes part of Western Asia, mainly Asia Minor (Turkey) and adjacent small part of Syria. Therefore, this range does not encompass the Northern Anatolian Mountains, i.e. Pontic Mountains and their northern, far more humid or perhumid slopes that face to the Black Sea (annually rainfall in Lazistan ranges from 2000-3000 mm per 
year), and then, Western Transcaucasia (south Colchis); secondly, the moth's range in Asia Minor is characterized by disjunct distribution (see map): a) population of Central Taurus Mts, i.e. mountain complex dividing the Mediterranean coastal region of southern Turkey (prov. Antalya) from the central Anatolian plateau; b) population of the upper reaches of the Euphrates River (Eastern Anatolia); c) population of surrounding the city of Elazig (Eastern Anatolia); d) population of Hakkari Province (the southeastern corner of Anatolia) and adjacent Syria. The largest range of discussed moth is represented in Central Taurus Mts, where $B$. ledereri was collected together with other moths, Saturnia pyri, Nola ronkayorum, etc. [58]; thirdly, ecological requirement of $B$. ledereri in mentioned sites of Turkey is quite different from those of represented in hygro-mesophilous relict mixed forests of Colchis. In Asia Minor this species prefers chiefly deciduous forests limited by riparian gallery forest represented in riversides of gorges and valleys of local mountains. Dominant vegetation composed of woody species, such as Fraxinus excelsior, Platanu ssp., Eleagnus angustifolia, secondary wild grapevine (Vitisvinifera), fig tree (Ficuscarica), hazel-nut (Corylussp.), etc. As a result of human activities surrounding landscapes in some regions support only sparsely treed forests consist of overstory deciduous and evergreen species of oak (Quercus infectoria, $Q$. libani, $Q$. persica). Understory represented by species of Crataegus, Prunus, Lonicera, Sorbus, Juniperes and others. Leaf feeding caterpillars are found only on ash tree (F. excelsior).

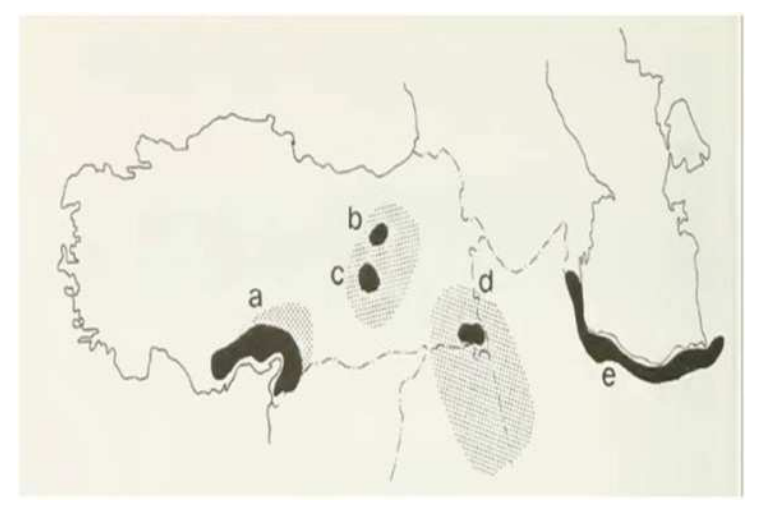

Figure 10. The distribution sites of BrahmaealedereriRogenhofer, 1873 in southern Caspian basin area and Anatolia plateau: a) Brahamea ledereri ledereri Freina de, Taurus Mts population; b) the same subspecies population in the upper reaches of Euphrates River (site Tanyeri); c) the same population in Elazig; d) B. ledererizabaFreina de, population from Hakkari; e) $B$. ledererichristophi (Stgr.) from Alborz and TalyshMts area [25].

It seems that in studied area Lederer's moth occurs from 1,000 to $2,000 \mathrm{~m}$ a.s.1. The lower amplitude of altitudinal distribution of the moth found in the central Taurus (1,000-1,600m), the highest elevation moth reaches occurs about 1,800m (upper reaches of the Euphrates River), and in Hakkari province the altitudinal distribution areas varies from 1,200 to $1,650 \mathrm{~m}$.

Riparian forests, which are surrounded by xeric shrublands and patches of sparsely forested sites, dramatically reduced by human's activity from the historical past. Thus, this is a wide spectrum of semi-arid habitats with clearly expressed sub-Mediterranean climate (Taurus Mts) location (a) and continental climate locations $(b, c)$, or sharply expressed continental climate (very hot and dry summer and cold winter) location (d) sites of Turkey (see fig. 1).

Vicariant event, in which part of a once widely distributed population of Brahmid moth becomes isolated in a spacially localized patches in Turkey, should be explained by intense folding of the Anatolian plateau. This tectonic event that caused this local landmass to emerge and largely change its morphology is the eastward displacement of the Anatolian microplate, driven from the northward displacement of the Arabian plate [59], considerably after rising Anatolian diagonal, which caused the separation of East and West Anatolian biota [60].

Current distribution area of Lederer's moth is considered with suggestion of Tarkhnishvili et al. [10]. From these authors, viewpoint during Last Glacial Maximum climates suitable for forest vegetation existed in six regions of western Asia: Colchis, western Anatolia, western Taurus, and upper reaches of the Tigris River, Levant and the southern Caspian basin. Currently, among named six regions the most biodiverse area of the forests is represented only in Colchis and Hyrcania but other four regions are almost treeless, although, as it seems, deforestation within the Fertile Crescent region, i.e. cradle of agriculture caused by human activity [61]. Now only in some gorges of Anatolia plateau survive the derivatives of former mesic forests just in these microrefugial shelters are found some forest biome dependent invertebrate fauna including $B$. ledereri. Thus, current range oftwo sister species of Brahmaea (B. ledereri and B. christophi) have shaped an area from southern Caspian basin to the headwaters of the Euphrates and on the other hand to the Mediterranean basin (Central Taurus).

According to Freina [25], the possible range of $B$. ledereri is not investigated in adjacent to eastern Anatolia, northern Iraq and Zagros Mountain range (Iran).

Did the mesic forests actually occur during LGM in the Zagros Mts, which currently have covered by quite different biomes in result of the xerophilization of the whole region? Neontological data support the presence of isolated refugia in the central Zagros Mts, i.e. in the Irano-Turanian part of Iran. In this site of range at an altitude of $1,730 \mathrm{~m}$ a.s.l., annual precipitation about $600-700 \mathrm{~mm}$ and with very cold winter, but much of winter precipitation is snow, which cover the area until the end of March. In this area was discovered disjunct stand, remnant population of Pterocaryapterocarpa ( $P$. fraxinifolia) [62].

At first glance this extraordinary discovery confirms that in Late Tertiary some gorges of Zagros Mts were not extensively influenced by continental climate and were covered by thermophillousArcto-Tertiary communities of plants resemblance of Euxino-Hyrcanian forests. Hence, these mountainous systems as a natural bridge between Alborz and Taurus Mts have provided to be effective area to harbor some relict representative of the Tertiary biota including with a high 
probability $B$. ledereri. In other words Zagros Mts might have played a role of transitional area to connect the Hyrcanian refugee center of the Caucasus Ecoregion with those of cryptic glacial refugia of Asia Minor and other regions of the Near East.

On the base of the present (real) and imaginative (speculative) distribution of two species of the genus Brahmaea should be proposed the following range of the moth in a southern Caspian Sea area (northern Iran) on the one hand, and Anatolia plateau on the other hand. Within large refugium two taxa are concentrated from AlborzMts (in general Hyrcania), then throughout with larger probability of the occurrence in a dry segment of the Zagros Mts, and via extreme eastern part of the Anatolia plateau to the Taurus Mts (upper reaches of the Euphrates River), almost adjacent to its western part of the Mediterranean Sea.

The present-day distribution of two taxa of Brahmaea reflects a history of past wide distribution of tropical-subtropical and Arcto-Tertiary biotas, which today is largely replaced by modern, increasingly impoverished Hyrcanian nemoral biota and Anatolian Turkey plateau's semi-deserts with gorges sheltering some remain of former TBDF forests.

As we see this disjunct range of two species of the genus Brahmaeais distinguished by various climatic characteristics, the orographic heterogeneity, the geological and edaphic conditions as well as human impact considerably in Fertile Crescent area.

Among above indicated six regions, where the scientists hypothesize the presence of forest refugia there, the largest and most forested, major refugia is Colchis.

Therefore, in westernmost stretches of the Transcaucasia, in Colchis as well as in Hyrcania, an independent population of Brahmaea should be survived. This region with northern slopes of Pontic Mts undoubtedly satisfy the relict moth's ecological requirements. But today the eastern and south-eastern Black Sea coastal area should be considered as the region outside the confirmed refugium, where Brahmaea moth truly survived. On the other hand, without paleontological data there is no reason to postulate that some bottleneck event took place on the territory of Asia Minor.

Thus, recognizing this assumption as though $B$. ledereri lived in Colchis appears to be erroneous, I [27] hypothesize an extreme version of scenario to formation of the range of both paleoendemic taxa of Brahmin moths in Asia Minor and southern Caspian basin (Hyrcania). Under the most likely simulation regarding to origin of the common ancestor of ledereri-christophie volutionary lineage should be occurring within four or five forested or suggested mesic forest vegetation regions of Western Asia, most of which are represented today as cryptic refugia. Among six LGM refugial regions $B$. ledereri should be excluded from Colchis refugium. At the same time we once more emphasized that there are no abiotic factors, which made it an endangered and extinct species.

Floristic and faunistic studies of Indo-Malayan and other tropical origin species of Hyrcanianrefugium (species of
Albizia, Gleditsia, Panthera (including P. tigris, P. pardus), Hytrix, Brahmaea, etc.), support a viewpoint of the above modelling simulation.

There are some other explanations, which should be used as an additional suggestions for my [27] personal view. For example, geographical (latitudinal) and biogeographical (hystorical) reasons. In general, for all mentioned thermophilous tropical-subtropical species from northern margin of the tropical-subtopical latitudes (i.e. Hyrcanian part of Iran and Azerbaijan Republic) Colchis temperate climate latitudes with its abiotic factors, including, except temperature and precipitation, also photoperiodism, are insuperable ecological and geographical (latitudinal) barrier, preventing further northward distribution of Brahmaea'sautoecology organisms. It is worthy to remember, that the Hyrcanian refugium is located $4^{0} \mathrm{c}^{0}$ southward thanthat of the Colchis refugium.

Unlike Colchis, for a long time of historical past, south and south-eastern Asia, as a part of Oriental zoogeographic region, was an important contributor to the Hyrcanian part of northern Iran provided northern territories with thermophilous tropical species [7, 63].

This straight biological connection between two remote regions was shifted during the current (Quaternary) series of large-scale environmental changes (glacial events) causing desertification of some regions of Near East including central and eastern parts of the Iranian plateau. This dryland area converted into bottleneck to decrease the potential to expansion of thermo- and hygrophilous species in some marginal areas of higher latitudes of subtropic and subtropic-temperate border areas.

Thus, few species of the ancient genus Brahmaea (some species of which are found in tropics and subtropics) are scattered now within such remote but from climatic viewpoint more or less similar (except part of Golestan province of Iran and Anatolian Plateau) places of Northern Hemisphere.

On the example of allopatrically dispersed species united in genus Brahmaea, could be provided valuable information for our understanding of global climate changes patterns, its influence of living organisms eliminations and surviving processes, the role of harbours - refugia - during major Ice Ages in preservation some archaic thermophilous plant and animal taxa of Tertiary Period [27].

\section{Conclusions}

Comprehensive analysis of vicarious event between two species of Brahmid moths - Brahmaea ledereriand $B$. christophi as though occurring in two refugia of Transcaucasia, Colchis and Talysh, opened new views and permit provide another conclusions. Here, on the base of research the ranges of two species of peacockbutterflies and their bioecology, carrying out mainly by some entomologists [23,34-35] we pointed out another relation between Euxino-Hyrcanian and Anatolian biotas. There are actually allopatric ranges of two relict species of moths, but the disjunction has occurred not between relict moths of Brahmeidae of Colchis and Hyrcanian 
refugia, as it was accepted as an unconditionally dogma among Soviet Union's entomologists. Split the common range of genus Brahmaea, as it seems, actually took place in geological past (Pliocene), although not between Transcaucasian two famous refugia - Colchis and Talysh but between Hyrcanianrefugium on the one hand, and Anatolian cripticrefugial areas, on the other hand [27].

The latter region is represented at more lower $\left(35^{0}-38^{0}\right)$ latitudes unlike the Colchis occurring at higher latitudes $\left(40^{0}-45^{0}\right)$. This geographical phenomenon, as it seems, became major distributional limit ecological factor, preventing penetration complex of subtropical (Hyrcanian/Anatolian) organisms including B. ledereri within Colchis.

Despite its prehumid and warm climate of Colchis Triangle, one of the main abiotic factors - seasonal (insufficient) cycles of light (photoperiodism) became unsuitable for $B$. ledereriand another organisms of its autoecology, whereas at lower latitudes light is available for the same complex of organisms during year-round.

\section{Acknowledgements}

Research partially supported by CEPF (2005-2006) (research project 'Biodiversity Hotspots - Caucasus') [42]. We thank MrRastaghi the director of the Golestan National Park and its staff; the great help of PhD student Mahmoud Soufi and his family are appreciated for support of my trip to Golestan province, Dr. Eslami from the University Natural Science and Agricultural (city of Qaemshahr) for providing the research activity of MazandaranHyrcanian forested areas (Iran). The same support from director of Mtirala National Park (Adjara), D. Khomeriki; head of zoological expeditions in Turkey(2005-2007), Prof. R. Zhordania. We are much indebted to LaliGegechkori (Tbilisi) for linguistic improvements.

\section{References}

[1] A. Engler, „Versuch einer Entwicklungsgeschichte insbesondereder Pflanzenwelt seit der Tertiärperiode,“ II.Leipzig: Wilhelm Engelmann. 1882, 14,p. 386.

[2] D. I. Axelrod, "Origin of deciduous and evergreen habits in temperate forests," Evolution,1966,20, 1,pp. 1-15.

[3] H. Walter, „Die Vegetation der Erde,“ Vol. I. Progress, Moscow, 1968,p. 422. (translation in Russian).

[4] A. N. Kryshtofovich, "The main characteristic feature of development of the Tertiary flora of Asia," Izv. Glavn. Botan. Sada RSFSR, 29, 1930, 3-4, pp. 391-401. (in Russian).

[5] A. G. Dolukhanov, "Forest vegetation of Georgia," Universal, Tbilisi, 2010,p. 532 (in Russian).

[6] L. Williams, N. Zazanashvili,G..Sanadiradze, A. Kandaurov, (Eds.) "An Ecoregional ConservationPlan for the Caucasus," WWF, KFW, BMZ, CEPF, MacArthur Foundation. Tbilisi, Printed by Signar Ltd, 2006,p. 222.
[7] A. M. Gegechkori, "The results of biogeographical study of Arcto-Tertiary refugia (Colchis and Talysh) of the southern Caucasus," Annals of Agrarian Science, 2011a,9,1:16-33pp.

[8] A. A. Grossheim, "Flora of Talysh," Izd. Narkomzem Azerb. SSR, Tiflis, 1926,p. 273.

[9] K. Browicz, "Chorology of the Euxinian and Hyrcanian element in the woody flora of Asia, "Plant Systematics and Evolution", 1989, 162, pp. 305-314.

[10] D. Tarkhnishvili, A. Gavashelishvili, L. Mumladze, "Palaeoclimatic models help to understand current distribution of Caucasian forest species," Biol. J. Linn. Soc: 2012, 105, 1, pp. 231- 248 .

[11] A. M. Gegechkori, "Biogeographical characteristic of the Tertiarian organisms of the Talysh part (South Caucasus) of the Hyrcanian refugium," Annals of Agrarian Science, 2012b, 10, 1,pp. 8-16.

[12] N. Myers, R. A. Mittermeier, C.G. Mittermeier, G. A. B. da Fonseca, J. Kent, "Biodiversity Hotspots for conservation priorities,” Nature," 2000, 403, pp.853-858.

[13] J. Minet, "The Bombicoidea: Phylogeny and higher classification (Lepidoptera: Glossata), "Entomologica scandinavica," 1994, 25, 1, pp. 63-88.

[14] H. F. Chu, W. Ling-Yao, "The Brahmaeidae of China (Lepidoptera),"Acta Entomologica Sinica, 1997, 20,1, pp. 83-86.

[15] R. Spicciarelli, „La psichedel Frassino: European owl moth. Consiglio Regionale della Basilicata,“ Finiguerra Arti Grafiche-Lavello (pz), 2004,pp. 67-72.

[16] A. Marson, Rearing \& breeding, Brahmaea hearseyi in the UK.huffmantaxidermy.com/.../amarsonrearing.htm. 2004.

[17] P. C. Rougeot, "Les Bombycoides (Lepidoptera-Bombycoidea) de l'Europeet du BassinMēditerranēen, Tome I: Lemoniidae, Bombycidae, Brahmaeidae, Attacidae, Endromididae. Fauna de l'Europe et du BassinMēditerranēen, “ Masson et Cie, Paris, 1971, 5, p. 159.

[18] W. A. Nässig, Treadaway, C. G. "The Brahmaeidae (Lepidoptera) of the Philippines," Nachrichten des Entomologischen Verein Apollo Suppl., 1998,17, pp.425-440.

[19] J. B. Heppner, "Brahmin moths (Lepidoptera: Brahmaeidae)," Encyclopedoa of Entomology. Springer, 2008. pp. 561-562.

[20] J. W. Brown, "Records of Hypaurotis crysalus (Edwards) (Lycaenidae) from Western Mexico," Journal of Research on the Lepidoptera, 1988(89),27,2,pp. 135-143.

[21] W. A. Nässig, I. W. B. Nye, "Brahmaea Walker, 1855 (Insecta, Lepidoptera): proposal confirmation of Bombyx certhia Fabricius, 1973 as the type species," Bulletion of Zoological Nomenclature, 1991, 48, 2,pp. 137-139.

[22] A. W. Nässig, S. Naumann," Saturniidae and Brahmaeidae of the Palearctic Region: how many species are there?" Entomologica Romanica,2010,15, pp. 17-20.

[23] De. J. J. Freina, "Neuere kenntnisseüber die Biologie und Systematik von Brahmae ledereri Rogenhofer 1873. Und deren verbreitung in Kleinasien (Lepidoptera, Brahmaeidae), "Mitt. münch. ent. Ges., 1985, 74,pp. 77-90. 
[24] L. Lehmann, R. Zahiri, "Results of a lepidopterological expedition to North andNorthwest Iran in summer 2007 with new record for Iran (Lepidoptera) (plates 19-22)," Esperiana Band,2011, 16,pp. 135-165.

[25] De. J. J. Freina, "Eineneue population von Brahmaea ledereri Rogenhofer 1873 (Brahmaea ledereri zabassp.n. in Turkisch-Kurdistan, sowienachweis der konspezifitäz von Brahmaea ledereri Rogenhofer, 1873, und Brahmaea christophi Staudinger, 1879 (Lepidoptera, Brahmaeidae)," Entomofauna, 1982,3, 9,pp. 129-139.

[26] Ligustrumsinense. Chinese privet. In: wiki.bugwood.org/uploads/Ligustrum.pdf.

[27] A. M. Gegechkrori, "Has ever Brahmaea ledereri Rogenh. Inhabited the Colchis refugium unlike the Hyrcan refugium?" conference.ens-2015.tsu.ge./en/lecture/view/262. 2015.

[28] E. A. Didmanidze, "The butterflies of Georgia," Studia 99, Tbilisi, 2005,p. 85.

[29] O. Staudinger, H. Rebel, "Catalog der Lepidopteren des paläarktischen Faunengebieter,"Berlin, 1901, p. 411.

[30] E. Didmanidze, N. Goginashvili, "On the existence of Lederer's Brahma (Lepidoptera, Brahmaeidae) in the biomes of Georgia“, Report (Rustaveli National Science Fundation Grant, \#1-8-38), 2012, pp. 1-9 (in Georgian).

[31] M. A. Ryabov, "Butterflies (Lepidoptera) of the Caucasus," In: Zhivotni Mir Kavkaza [Animal World of the Caucasus]. Izd. AN SSSR, M.-L. 1958, 5, pp. 351-375 (in Russian).

[32] A. A. Mirzoyan, I. D. Batiashvili, "Rare insects," Lesnaia Promishlennost, Moscow, 1982. p. 165. (in Russian).

[33] A. M. Borodin, A. G. Bannikov, V. E. Sokolov, [Eds.] "Red Data Book of the USSR,"Moscow. Lesnaya Promishlennost 1984, Vol. 1, pp. 279-280. (in Russian) .

[34] R. E. Effendi, "To study of peacock butterfly fauna of Transcaucasia (Lepidoptera, Saturnidae. Brahmaeidae)," Materiali Sessii Zakavkazia [Materials of Session of Transcaucasia], Tbilisi, 1968,pp.536-538 (in Russian).

[35] R. E. Effendi, "Some stages of formation of the Lepidoptera fauna of Transcaucasia", Zool. Zhurnal, 1971, 1,5, pp.696-703 (in Russian).

[36] R. E. Effendi, "Some relict and endemic species of Macrolepidoptera of Talysh" Materiali Sessii Zakavkazia Po Zaschite Rastenii [Materials of Session of Transcaucasia about Plant Protection], Erevan, 1967, pp. 545-547 (in Russian).

[37] S.V. Aliev, R. E. Effendi, Sh.Y. Abdulaeva, "Order Lepidoptera of butterflies (Saturniidae, pp. 247-248; Brahmaeidae, pp. 248-249),"In: Animal World of Azerbaijan, Vol.II. Invertebrates, PhylumArthropoda (Musaev, M.A. et al., Eds). Elm, Baku (in Russian), 1996.

[38] E. Didmanidze, N. Ninua, "Some groups of animals from Strict Reserves of subtropic zone of Transcaucasica," Tbilisi, Metsniereba, 1999, pp. 1-45 (in Russian).

[39] E. Didmanidze, I. Skhirtladze, N. Ninua, L. Gurgenidze, V. Chkhikvadze, "On some endemic, rare and disappearing species of the Georgian fauna: new approaches to problem solution," Tbilisi, Khatula,2002. p. 65. (in Russian with English summary).
[40] E. Didmanidze, V. Petrov, "Review of fauna of peakockbutterflies (Lepidoptera: Saturniidae, Brahmaeidae) of Southern Caucasus from collection of Georgian National Museum," Proceedings Natural and Prehistoric Section. Georgian National Museum, 2011, 3, pp. 166-181 (in Georgian, with English summary).

[41] A. M. Gegechkori, "Relicts and endemics and Georgia's biodiversity at the background of the Caucasus orogenesis," In: Biological and Landscapes Biodiversity of Georgia. WWF Georgia, Tbilisi, 2000, pp. 83-96 (in English and Georgian).

[42] A. M Gegechkori, "Caucasus - treasure of the Nature,"CEPF, WWF, Meridiani,2007, pp. 168. (in English and Georgian).

[43] A. M. Gegechkori, "Biogeography, chapter 1 (Biomes of the World),"Tbilisi StateUniversity Publ. House, 2008, p. 527 (in Georgian, with English summary and contents).

[44] A. M. Gegechkori, "The results of biogeographical study of Arcto-Tertiary refugia (Colchis and Talysh) of the southern Caucasus," Annals of Agrarian Science, 2011a, 9,1, pp.16-33.

[45] Z. Kikvidze, M. Oshawa, "Adjara. East Mediterranean refuge of Tertiary vegetation," In: Oshawa M. et al. - Eds. Chiba Univ., 1999, pp. 297-315.

[46] T. Denk, N Frotzler,. N. Davitashvili, "Vegetational patterns and distribution of relict taxa in humid temperate forests and wetlands of Georgia (Transcaucasia),"Biol. J.Linn. Soc. 2001, 72,2 , pp. 287-333.

[47] D. Tarkhnishvili, U. Kaya, A. Gavashelishvili, I. Serbinova, "Ecological divergence between two evolutionary lineages of the Caucasian salamander: evidence from GIS Analysis," Herpetological journal, 2008, 18, pp. 155-163.

[48] D. V. Mandjavidze, "Relict forests of Adjara," Metsniereba, Tbilisi (in Russian), 1982, p. 237.

[49] T. Gokturk, F. Bucak,T. Artvinli, "Mammalian fauna of Artvin, "African Journal of Agricultural Research, 2011, 6 (6), pp. 1418-1424 .

[50] E. Karaçetin, H. J. Welch, "Red Book of butterflies in Turkey," Doga Koruma Merkezi. Ankara, Turkey. 2011, pp. 1-125.

[51] A. M. Gegechkori, "The two refugia of the southern Caucasus, Colchis and Talysh: a comperative biogeographical analysis," International Conference of IGU, Santiago, Chile (acreditacion. fisa.cl/ugi/.../ 20112324VO3ZVH_f.doc.),2012a.

GegechkoriArnold_

[52] A. M. Gegechkori, H. Joosten, (Eds.) "The biomes of the Caucasus," Draft for the IMCG Field Symposium, Georgia/Armenia, Sept. 2009. Greifswald, 2009,p. 169.

[53] Red Data Book of Azerbaijan - Wikipedia. https://ru.wikipedia.org/.../Список_Насекомых_занесенных_ в_Красную. . .

[54] H. Mohammadian, "Biological diversity of Lepidoptera of Iran (Geographic distribution of 2200 species)," Shabpareh publications,2006, p. 386.

[55] L. Lehmann, R. Zahiri, "Results of a lepidopterological expedition to North and Northwest Iran in summer 2007 with new record for Iran (Lepidoptera) (plates 19-22),"Esperiana Band,2011, 16,pp. 135-165.

[56] List of moths of Iran - Wikipedia, the free encyclopedia 2014.en.wikipedia.org/wiki/List_of moths_of_Iran. 
[57] M. Sharifi, "An overview of ecological potential and the outstanding universal value offorests resources of I. R. Iran with respect to climate change,"Regional Workshop 'Forests, Rangelands and Climate Change in the Near East Region' 20-22 September, 2011, Cairo, Egypt, 2011, pp. 1-10.

[58] S. Beshkov, "Nola ronkayorum sp. n., a new species from Bulgaria and Turkey (Lepidoptera: Nolidae)," Phegea, 2006, 34(1), pp. 17-32.

[59] P. Lymberakis, N. Poulakakis, "Three continents claiming an archipelago: the evolution of Aegean's herpetofaunal diversity," Diversity,2010,2, pp. 233-255.

[60] P. H. Davis, "Distribution patterns in Anatolia with particular reference in endemism," In: Davis, P. H., Harper, P. C., Hedge, I. C. (Eds.). Plant life of Southwest Asia. Royal Bot. Gard., Edinburgh, 1971, pp. 15-27.
[61] D. Zohary, M. Hoph, E. Weiss, "Domestication of plants in the Old World," Oxford UniversityPress, 2012, pp. 1-280.

[62] H. Akhani, M. Saliman, "An extant disjunct stand of Pterocarya fraxinifolia (Juglandaceae) in the central Zagros Mountains," W. Iran. Willdenowia, 2003, 33, pp. 113-120.

[63] N. K. Vereshchagin, "Mammals of the Caucasus,".In: Zhivotni Mir SSSR[Animal World of the USSR], 1959.V 5. Izdatelstvo AN SSSR,M.-L. (in Russian), p. 704.

[64] Lederer'sbrahmin, sin: http://ru.wikipedia.org/wiki/Брамея-Ледерера

[65] N. M. Romanoff, "Les Lepidopteres de la Transcaucasie," In: Memuares sur les Lepidopteres'. St.-Petersbourg, 1885. v.2, pp. $3-118$. 